\title{
POTENTIAL OF METHANE AND CARBON DIOXIDE IN VITRO PRODUCTION BY Urochloa HYBRID SUBJECTED TO PERIODS OF COEXISTENCE WITH WEEDS
}

\author{
POTENCIAL DE PRODUÇÃO IN VITRO DE METANO E DIÓXIDO DE CARBONO \\ PELA Urochloa HÍBRIDA SUBMETIDA A PERÍODOS DE CONVIVÊNCIA COM \\ PLANTAS DANINHAS
}

\author{
Edenilson MEURER ${ }^{1}$; Sara Carvalho de BRITO ${ }^{1}$; Sidnei Roberto de MARCHI $^{{ }^{*}}$; \\ Guilherme Henrique Rodrigues PINHEIRO ${ }^{2}$; Dagoberto MARTINS $^{3}$ \\ 1. Universidade Federal de Mato Grosso, Campus Universitário do Araguaia, Barra do Garças, MT, Brasil. \\ sidneimarchi.ufmt@gmail.com*; 2 Universidade Federal de Goiás, Regional Jataí, Jataí, GO, Brasil; 3. Faculdade de Ciências Agrárias \\ e Veterinárias - FCAV, Universidade Estadual Paulista - UNESP, Departamento de Produção Vegetal, Jaboticabal, SP, Brasil.
}

\begin{abstract}
The increased world population has raised the demand for animal proteins, forcing livestock to become productive, efficient, and environmentally sustainable. This study aimed to assess the effect of weed coexistence on productivity, nutritional quality, and potential production of greenhouse gases (GHG) by Convert HD364 grass (Urochloa hibrida cv. Mulato II) under pasture renovation conditions. The experiment was carried out in a randomized block design with four replications and treatments consisting of eight coexistence periods: $0,15,30,45,60,75,90$, and 120 days after seedling emergence. Phytosociological assessments were performed in the weed community at the end of each coexistence period. The Convert HD364 grass was assessed for the morphological and chemical-bromatological parameters and for the GHG emission potential. Productivity, nutritional quality, and energy value of the Convert HD364 grass decreased proportionally with the increased period of weed coexistence. The non-coexistence with weeds results in a better in vitro digestibility of organic matter and, consequently, decreases the potential of GHG emission by the dry matter of the Convert HD364 grass.
\end{abstract}

KEYWORDS: Urochloa hibrida cv. Mulato II. Morphometry. Productivity. Nutritional quality. Digestibility. Energy value.

\section{INTRODUCTION}

Forage species have an essential role for grazing ruminants since the profitability and sustainability of this system depend on the choice and nutritional quality of the plants, directly affecting zootechnical indices and socioeconomic aspects of the majority of tropical countries (GLÉRIA et al., 2017). It's noted that the grasses of the genus Urochloa (syn. Brachiaria) are among the exotic forages currently cultivated in Brazilian pastures due to their adaptation to the most adverse climatic and soil conditions, dominating widely on the other genera of forages used in the Cerrado environment (MARCHI et al., 2017).

More recently, hybrids have been developed in order to more efficiently convert natural resources into different final products of livestock, thus guaranteeing higher productivity in a smaller area and shorter time. A typical example is Urochloa hibrida cv. Mulato II, commercially known as Convert HD364, obtained by the cross between Urochloa ruziziensis $\mathrm{x}$ Urochloa decumbens $\mathrm{x}$ Urochloa brizantha, which was selected for its resistance, vigor, and high digestibility. Results have shown that this forage has the potential to produce from 10 to $27 \mathrm{t} \mathrm{ha}^{-1}$ year ${ }^{-1}$ of dry matter with good nutritional value (ARGEL et al., 2007; VENDRAMINI et al., 2012; SANTOS et al., 2015).

The nutritional value of a food, on the other hand, is the measure of its capacity to sustain groups of metabolic activities inherent to the animal organism (BLAXTER, 1956). In the case of ruminants, this analysis involves the study of the nature of digestion products, its chemical composition (concentration of structural and nonstructural carbohydrates, proteins, and lipids), and its digestibility. In addition, in the case of forage grasses, the analysis of the ability to sustain groups of metabolic activities encompasses, among other things, assessments of crude protein, structural carbohydrates, neutral detergent fiber, and in vitro digestibility of organic matter (LEAL et al., 2017). 
In turn, when the ingested forage reaches the rumen, most of the nutrients in the food, especially energy and protein sources, are transformed into short-chain fatty acids, microbial mass, and gases such as methane $\left(\mathrm{CH}_{4}\right)$, carbon dioxide $\left(\mathrm{CO}_{2}\right)$, and hydrogen $\left(\mathrm{H}_{2}\right)$ (BAKER, 1999). Methanogenesis is part of the normal digestive process of ruminant herbivores and is directly related to $\mathrm{H}_{2}$ concentration in the rumen. It is estimated that the production and emission of methane in ruminants lead to significant losses ranging from $4 \%$ to $12 \%$ of the total crude energy ingested in the feed (PEDREIRA et al., 2005).

It is known that methane emission per unit of ingested dry matter is higher in foods of lower quality and lower energy density (PRIMAVESI et al., 2004). The increase in dry matter intake conditions the linear increase in methane production head $^{-1}$ day $^{-1}$ for animals consuming forage, while this relationship is inverse between methane production per kilogram of ingested dry matter with better values of total digestible nutrient (TDN) for the same dry matter intake (BERCHIELLI; MESSANA; CANESIN, 2012).

However, the quality and production capacity of forages are intrinsically related to the environmental conditions prevailing in the area and adopted management practices. Factors such as temperature, light, water, and nutrients may condition the photosynthetic potential of the forage canopy due to changes in leaf area and photosynthetic capacity of the plant (VENDRAMINI et al., 2012; SANCHES et al., 2013; SANTOS et al., 2015).

In addition to the mentioned abiotic factors, some biotic factors may also alter the productivity of forage plants. Among the several biotic factors, the presence of weeds determines the action (or causes change in the intensity of action) of several ecological factors, some favorable and others unfavorable to the interests of the cattle breeder. The main problem caused by weeds is the direct competition for space, light, water, and nutrients, causing a reduction of the physiological reserves of forages (SANTOS et al., 2011). When competing for growth factors, weeds can also provide decreases in the nutritional value and pasture support capacity, provide an increase in the time of pasture formation and recovery, cause injury and/or intoxication to animals, and compromise the aesthetics of the property (MARCHI et al., 2017; BELLÉ et al., 2018; MARCHI et al., 2019).

Considering that gas production varies according to the quantity and quality of the food ingested by the animal and that weeds can influence these two characteristics of tropical forages (MARCHI et al., 2017; BELLÉ et al., 2018; LOURENÇO et al, 2019), this research aimed to study the interference relationships of weeds on productive components, nutritional quality, energy potential, and production potential of GHG by the Convert HD364 grass under pasture renovation conditions.

\section{MATERIAL AND METHODS}

\section{Area Description}

The experimental phase of this research was carried out in a degraded pasture area located at the geographic coordinates 15'52'29" S and 52 18"37" WGr. from December 2013 to May 2014. The weather of the region is Aw according to the Köppen classification. It is characterized by average temperatures above $27^{\circ} \mathrm{C}$ in the hottest months (November to February), average temperatures over $18^{\circ} \mathrm{C}$ in the coldest months (June to August), and average annual rainfall between 1,000 and 1,500 $\mathrm{mm}$, distributed in two well-defined periods: a season of intense rains from October to March and a period of drought between April to September (ALVARES et al., 2014).

The soil of the area is classified as a dystrophic Red-Yellow Latosol, and had the following chemical and physical characteristics: $\mathrm{pH}$ in $\mathrm{CaCl}_{2}$ of $4.3,22.0 \mathrm{~g} \mathrm{dm}^{-3}$ of organic matter; 3.8 $\mathrm{mg} \mathrm{dm}{ }^{-3}$ of $\mathrm{P}$ resin; $\mathrm{V}$ of $23.5 \%$; contents of $\mathrm{K}$; $\mathrm{Ca}$, $\mathrm{Mg}$ and $\mathrm{H}+\mathrm{AL}$ of $0.15 ; 0.66,0.42$ and $4.0 \mathrm{cmolc}$ $\mathrm{dm}^{-3}$, respectively; $692 \mathrm{~g} \mathrm{~kg}^{-1}$ of sand; $97 \mathrm{~g} \mathrm{~kg}^{-1}$ of silt and $211 \mathrm{~g} \mathrm{~kg}^{-1}$ of clay; which characterizes it as having a sandy loam texture.

The area preparation was carried out initially by eliminating the existing vegetation by a post-emergence application of herbicide glyphosate at $3.0 \mathrm{~L} \mathrm{ha}^{-1}$. After, soil fertility was corrected according to the recommendations of Vilela et al. (2004), by which the equivalent of $2,000 \mathrm{~kg} \mathrm{ha}^{-1}$ of limestone was applied to raise the base saturation to $50 \%$. Later, a procedure of incorporation of limestone and elimination of vegetal remains was performed. Sowing fertilization consisted of $250 \mathrm{~kg}$ $\mathrm{ha}^{-1}$ of the formulation 5-25-15 (N-P $\left.\mathrm{O}_{5}-\mathrm{K}_{2} \mathrm{O}\right)$, manually distributed over the soil surface.

The sowing of Convert HD364 grass was carried out at the beginning of the rainy season with a uniform grain distribution machine applying the equivalent of $8.0 \mathrm{~kg} \mathrm{ha}^{-1}$ of seeds. Soon afterwards, the seeds were manually incorporated to the soil at the average depth of $2.0 \mathrm{~cm}$ using a comb.

The experiment design was arranged according to a randomized complete blocks design 
with four replications. The treatments consisted of eight periods of coexistence between weed community and forage grass $(0,15,30,45,60,75$, 90 and 120 days after the emergence of plants DAE). The period of 120 days was determined according to necessary time to obtain adequate grazing conditions of grass Convert HD364 after sowing (ARGEL et al., 2007). The treatment equivalent to 0 (zero) day was considered as the absolute control, in which there was a total absence of coexistence between weeds and forages during the entire period of conduction of the experiment.

\section{Weed community evaluation}

The characterization of the weed population was performed by phytosociological survey at the end of each coexistence period. The evaluations were carried out in the useful area of each experimental plot using a $0.50 \mathrm{~m} \times 0.50 \mathrm{~m}$ plastic frame randomly placed inside the plots. The species forming the weed community inside the frame were identified, numerically quantified and taken to the laboratory. Then, they were washed, packed in paper bags and dried in a forced-air circulation oven at $65^{\circ} \mathrm{C}$ for 72 hours until constant weight. After this procedure, the dry biomass of shoots of the collected species was determined using a precision scale of $0.01 \mathrm{~g}$. The relative importance of the species (RIs), which simultaneously expresses the density, dominance and frequency of the individuals present in the weed community (MONQUERO; HIRATA; PITELLI, 2014), was determined by the number and dry biomass of plants.

At the end of each coexistence period, the weed community was removed from the plot by application of $1.5 \mathrm{~L} \mathrm{ha}^{-1}$ of herbicide formulated on the basis of $40 \mathrm{~g} \mathrm{~L}^{-1}$ of acid equivalent of aminopyralid $+320 \mathrm{~g} \mathrm{~L}^{-1}$ of acid equivalent of 2,4-D applied at plant post-emergence. Applications of the herbicide were carried out whenever necessary with a $\mathrm{CO}_{2}$ pressurized spray containing a four-tip spreader bar XR 11002 calibrated to dispense the spray volume equivalent to $200 \mathrm{~L} \mathrm{ha}^{-1}$.

\section{Forage morphostructural characteristics}

The morphometry and the structure of Convert HD364 grass were evaluated at the end of the experiment period, that is, at 120 days after emergence (DAE) of seedlings. At this point, tiller height $(\mathrm{cm})$, tiller diameter $(\mathrm{mm})$, height of the first green leaf $(\mathrm{cm})$, number of green leaves and number of dry leaves were determined in ten tillers randomly collected within each plot. The tillers were then fractionated into leaf and stem, and the dry biomass of the respective fractions was obtained according to the aforementioned methodology. It was possible to determine the relation between leaf dry biomass / stem dry biomass (leaf/stem) using the dry biomass data. The ratio tiller height/height of the first green leaf (HT/HFGL) was determined using height data.

The productivity of Convert HD 364 grass was also evaluated at 120 DAE. We collected samples by cutting the plants at $10 \mathrm{~cm}$ of height from the soil surface within the area delimited by the of $0.50 \mathrm{~m} \times 0.50 \mathrm{~m}$ plastic frame. The samples were randomly chosen within the experimental unit. Then, they were taken to the laboratory and fractionated into green leaves, green stems and dead matter. The dry biomasses of green leaf $(\mathrm{g})$, green stem $(\mathrm{g})$, dead matter $(\mathrm{g})$ and total matter $(\mathrm{g})$ were obtained according to the methodology previously described. The inflorescences eventually existing were considered as green stems. With the dry biomass data it was possible to estimate the yield ( $\mathrm{g}$ $\mathrm{m}^{-2}$ ) of respective fractions.

\section{Forage nutritional quality}

Other samples of forage grass were collected at $120 \mathrm{DAE}$, and dried in the laboratory as mentioned previously, but without any fractionation. The dried samples were then ground in a Willey mill until they reached a particle size of $1.0 \mathrm{~mm}$.

Half the milled samples were sent to the laboratory to determine crude protein $(\mathrm{CP})$, neutral detergent fiber (NDF), acid detergent fiber (ADF) and indigestible neutral detergent fiber (iNDF) as proposed by Silva and Queiroz (2002). The analyses of acid detergent insoluble nitrogen (ADIN) and acid detergent fiber-bound nitrogen (N-ADF) were performed according to the methodology proposed by Licitra, Hernandez and Van Soest (1996). The analyses of in vitro digestibility of organic matter (IVDOM), total digestible nutrient (TDN), digestible energy (DE) and metabolizable energy (ME) were performed as proposed by Seker (2002).

The levels of CP, NDF, FDA, ADF, iNDF, ADIN, N-ADF and IVDOM are expressed as dry matter percentage (\%DM), and $\mathrm{DE}$ and $\mathrm{ME}$ values are expressed as mkal kg-1 of DM.

\section{Potential in vitro gas production}

The other half of the ground samples was used to evaluate Convert HD364 grass as for the potential production of total gas, $\mathrm{CH}_{4}$ and carbon dioxide $\left(\mathrm{CO}_{2}\right)$, following a methodology adapted and proposed by Paschoaloto et al. (2016), where the gas produced over a 24-hour period is expressed as $\mathrm{mL} \mathrm{g}^{-1}$ of $\mathrm{DM}$. The gas concentration was 
analyzed using a Trace GC UltraTM gas chromatograph, Thermo Scientific.

\section{Statistical analysis}

The results of morphology, productivity, nutritional quality and gas potential production variables were subjected to analysis of variance by $F$ test using the AgroEstat statistical software (BARBOSA; MALDONADO JR., 2015). The effects of the treatments were compared by Scott Knott test $(P \leq 0.05)$ and are expressed as mean values. The results of the leaf/tiller and HT/HFGL ratios and the IVDOM, TDN, ME and DE values were submitted to regression analysis, and the degrees of freedom of the evaluated factor were unfolded into linear, quadratic and cubic effects by the software Origin 8.5.1 SR1. For the choice of the regression model, the highest value of the coefficient of determination $\left(\mathrm{R}^{2}\right)$ was taken into account at $\mathrm{p} \leq 0.05$, according to the $\mathrm{F}$ test, respecting the biological response.

\section{RESULTS AND DISCUSSION}

\section{Weather conditions and phytosociological analysis}

The mean daily temperatures were between
25 and $30{ }^{\circ} \mathrm{C}$, with an overall mean during the entire experimental period of $26^{\circ} \mathrm{C}$. The mean incident global radiation was $16.97 \mathrm{MJ} \mathrm{m}^{-2}$ day $^{-1}$ and the total precipitation in the period was $1242 \mathrm{~mm}$, representing means higher than $100 \mathrm{~mm}$ of precipitation per month.

The dependence of weather factors such as temperature and humidity are important characteristics for a good development of plants that have of C4-type metabolism of carbon dioxide assimilation. Because it is a tropical grass, the main weather conditions for the production of Convert HD364 grass are temperatures above $15^{\circ} \mathrm{C}$, minimum annual precipitation of $800 \mathrm{~mm}$, and incident global radiation of at least $12.0 \mathrm{MJ} \mathrm{cm} \mathrm{cm}^{-2}$ day $^{-1}$ (ARGEL et al., 2007; BITENCOURT JUNIOR; SIEWERDT; FERREIRA, 2008; FLEITAS et al., 2018). Thus, no restrictions of environmental factors were observed during the experimental period that could compromise the vegetative development of the Convert HD364 grass.

Eleven species were found in the assessments carried out in the weed community throughout the experimental period. These species were distributed into ten dicotyledons species and one of monocotyledons, as shown in Table 1.

Table 1. Scientific name, family, and international codes of weeds present in the experimental area

\begin{tabular}{lll}
\hline Scientific name & Family & International code \\
\hline Amaranthus retroflexus L. & Amaranthaceae & AMARE \\
Diodia teres Walter & Rubiaceae & DIQTE \\
Spermacoce latifolia Aubl. & Rubiaceae & BOILF \\
Waltheria indica var. americana (L.) P. Brow ex Hosaka & Malvaceae & WALAM \\
Sida rhombifolia L. & Malvaceae & SIDRH \\
Sidastrum micranthum (St.-Hill) Fry Xell & Malvaceae & SIDMI \\
Ipomoea grandifolia (Dammer) O'Donell & Convolvulaceae & IAOGR \\
Senna obtusifolia (L.) H.S.Irwin \& Barneby & Leguminoseae & CASOB \\
Hyptis suaveolens (L.) Point & Lamiaceae & HYPSU \\
Triumfetta bartramia L. & Tiliaceae & TIUBA \\
Cyperus difformis L. & Cyperaceae & CYPDI \\
\hline
\end{tabular}

The phytosociological study indicated that sicklepod (CASOB) presented the highest RI index up to 45 days of coexistence. From this period, pignut (HYPSU) also began to allocate considerable amounts of resources, presenting an RI of $30.8 \%$ in the period of 120 days of coexistence. Sida rhombifolia (SIDRH) and Spermacoce latifolia (BOILF) presented RI values between 10 and $20 \%$, characterizing them as intermediate species in terms of their relative importance among weeds. The other species had RI values below $10 \%$ regardless of the period in which the assessment was performed
(Figure 1).

Pasture renovation is the most rational solution for areas diagnosed as having an extreme degradation level, which consists basically in the destruction of old vegetation, soil fertility correction, and sowing of a forage species adequate to the local environmental conditions (MACEDO, 2009). However, all these activities are inefficient to eliminate the seed bank left in previous years by weeds, which will germinate together with forage seeds and soon begin a new degradation process (MARCHI et al., 2017). 


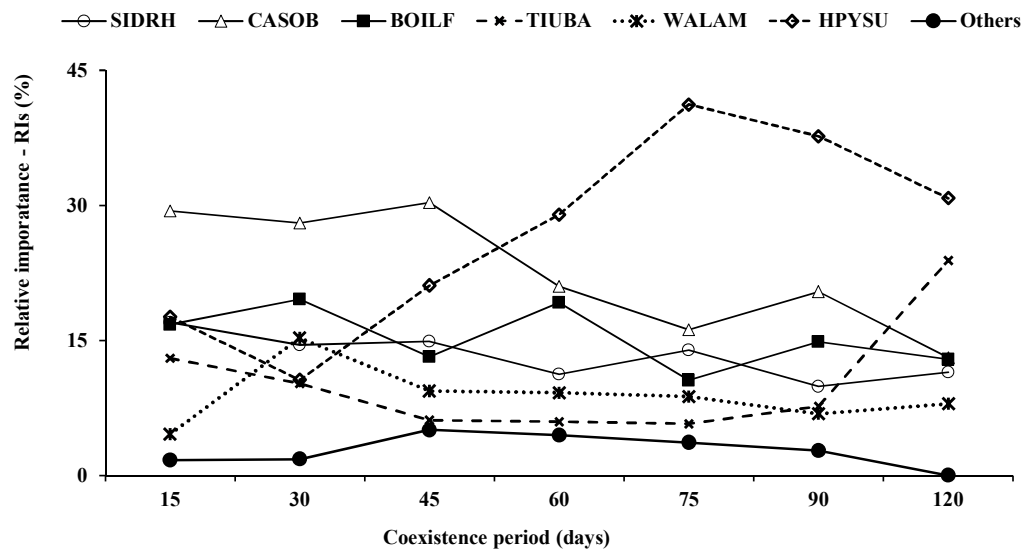

Figure 1. Relative importance (\%) of the weed community obtained in the respective coexistence periods. SIDRH - Sida rhombifolia. CASOB - Senna obtusifolia. BOILF - Spermacoce latifolia. TIUBA - Triumfetta bartramia. WALAM - Waltheria americana. HYPSU - Hyptis suaveolens.

The previous presence of weed seeds was confirmed in this study since eleven different species occurred throughout the experimental period, especially CASOB and HYPSU in terms of importance. These results corroborate a phytosociological study carried out by Marchi et al. (2017) and Bellé et al. (2018) on a pasture of Urochloa brizantha cv. Marandú. These researchers reported that $S$. obtusifolia, $H$. suaveolens, and $S$. rhombifolia were the species within the weed community that presented the highest indices of importance values.

The main fact to be highlighted in this study regarding the phytosociological assessment is that the presence of at least one weed species was always observed throughout the experimental period (Figure 1). Although, the individual relative importance has fluctuated (Figure 1), all eleven species together, i.e., the weed community, had the potential to establish a biological relationship of competition with the forage grass and thus possibly interfere with the development of the Convert HD364 grass.

\section{Morphology and structure of the forage}

All the variables related to the morphostructure of the Convert HD364 grass were influenced by weed coexistence. The coexistence period of 120 DAE conditioned a tiller height of $174.70 \mathrm{~cm}$, which is statistically higher than the heights obtained in the other studied periods (Table 2).

The effect of the presence of plants on tiller diameter was inverse to that observed in the height, in which the increased coexistence period conditioned decreases in the values of diameter in tillers of the Convert HD364 grass. In addition, only 15 days of coexistence were enough to significantly reduce the tiller diameter when compared to $0 \mathrm{DAE}$ (Table 2).

Weed coexistence also negatively influenced the number of green leaves produced by the Convert HD364 grass. The periods of 0 and 15 DAE produced, on average, 11.92 to 10.15 leaves per tiller, respectively, while the means obtained in the periods from 30 to 120 DAE were between 6.02 and 7.85 green leaves, respectively, which are statistically lower than the values obtained in other coexistence periods (Table 2).

However, the assessment of dead leaves showed the existence of three different levels of production, in which the statistically lower mean was obtained in the period of 0 DAE. The second level can be observed for values obtained in the periods of 15 and 30 DAE, followed by values found in the periods from 45 to $120 \mathrm{DAE}$, which are statistically higher than all observed in the previous coexistence periods (Table 2).

Changes in the morphometry of the Convert HD364 grass can also be noted through the relationship between the biomass of leaf and stem and the ratio between tiller height and first green leaf height. The increase in the coexistence period resulted in linear reductions in the leaf/stem ratio (Figure 2A), simultaneously to linear increases in the TH/ FGLH ratio (Figure 2B).

Tropical forages, once shaded, tend to increase stem elongation and leaf senescence in order to obtain sunlight and better survival conditions (CASAGRANDE et al., 2010), causing a 

the leaf/stem ratio, and hence lower forage intake by

Table 2. Height and mean diameter of tillers, first green leaf height (FGLH), and number of green (GL) and dry leaves (DL)

\begin{tabular}{lcccc}
\hline $\begin{array}{l}\text { Coexistence } \\
\left(\mathrm{DAE}^{\underline{1}}\right)\end{array}$ & Height $(\mathrm{cm})$ & Diameter $(\mathrm{mm})$ & $\mathrm{GL}$ & $\mathrm{DL}$ \\
\hline 0 & $127.32 \mathrm{~b}$ & $4.52 \mathrm{a}$ & $11.92 \mathrm{a}$ & $0.42 \mathrm{c}$ \\
15 & $114.50 \mathrm{~b}$ & $3.98 \mathrm{~b}$ & $10.15 \mathrm{a}$ & $1.25 \mathrm{~b}$ \\
30 & $130.05 \mathrm{~b}$ & $3.74 \mathrm{c}$ & $7.85 \mathrm{~b}$ & $1.60 \mathrm{~b}$ \\
45 & $131.30 \mathrm{~b}$ & $3.52 \mathrm{c}$ & $7.32 \mathrm{~b}$ & $2.12 \mathrm{a}$ \\
60 & $137.50 \mathrm{~b}$ & $3.48 \mathrm{c}$ & $6.97 \mathrm{~b}$ & $2.43 \mathrm{a}$ \\
75 & $137.95 \mathrm{~b}$ & $3.47 \mathrm{c}$ & $6.87 \mathrm{~b}$ & $2.13 \mathrm{a}$ \\
90 & $138.15 \mathrm{~b}$ & $3.27 \mathrm{c}$ & $6.82 \mathrm{~b}$ & $2.55 \mathrm{a}$ \\
120 & $174.70 \mathrm{a}$ & $3.21 \mathrm{c}$ & $6.02 \mathrm{~b}$ & $2.65 \mathrm{a}$ \\
\hline F Coexistence & $5.67^{* *}$ & $9.02^{* *}$ & $8.05^{* *}$ & $5.66^{* *}$ \\
F Blocks & $1.45^{\mathrm{NS}}$ & $0.48^{\mathrm{NS}}$ & $0.31^{\mathrm{NS}}$ & $0.49^{\mathrm{NS}}$ \\
CV $(\%)$ & 10.67 & 7.82 & 17.67 & 33.76 \\
\hline
\end{tabular}

NS - Not significant; ** - Significant at 5\% probability. Means followed by the same letter do not differ statistically from each other by the Scott-Knott test at $5 \%$ probability.

$\lfloor 1$ DAE - Days after emergence.

Therefore, the increased height and decreased diameter of tillers, decreased green leaf production, increased number of dead leaves, decreased leaf/stem ratio, and elevated position of live leaves characterize plant etiolation, which is a typical behavior of plants submitted to a low luminosity condition (MARCHI et al., 2017). Thus, weed presence caused the shading of the forage grass and allowed the biological relationship of competition for the light factor to be established in the first fortnights of common coexistence, significantly altering the morphogenesis of leaves of the Convert HD364 grass.

Morphostructural changes provided by weed presence directly reflected on the productivity of the Convert HD364 grass since all the assessed variables presented statistically higher values under the condition in which it was not allowed weed coexistence, i.e., 0 DAE. Green leaf dry matter (GLDM), green tiller dry matter (GTDM), and dead material dry matter (DMDM) obtained during the coexistence periods of 15 and 30 DAE presented intermediate values and the other coexistence periods provided statistically significant lower values when compared to previous periods (Table $3)$.

The total dry matter (TDM), which represents the sum of dry matter of all fractions, shows that an increase in the weed coexistence provided progressive reductions in TDM values
(Table 3). The reductions were notorious $(\mathrm{P}<0.01)$ at $15 \mathrm{DAA}$, when the loss in dry matter productivity was $26.56 \%$. Reductions also occurred $(\mathrm{P}<0.01)$ in the periods of 30 and 45 DAS and represented losses of 34.83 and $41.25 \%$, respectively. However, even more expressive reductions $(\mathrm{P}<0.01)$ in the productivity of TDM occurred at periods equal to or higher than 60 DAE, with losses reaching the maximum level of approximately $62 \%$ at $120 \mathrm{DAE}$.

These results of productivity indicate that weed presence, in addition to competitively reducing the amount of produced food also changes pasture structure as a function of the differential use of photoassimilates by the Convert HD364 grass (VENDRAMINI et al., 2012; SANCHES et al., 2013; SANTOS et al., 2015) and, consequently, it changes the form in which the forage is available to the animal. This change in forage canopy may reduce the effectiveness of the animal grazing habit and, consequently, the profitability of the livestock activity (CARVALHO et al., 2016; MEZZALIRA et al., 2014; OLIVEIRA et al.; 2016, MARCHI et al., 2019).

In other words, the increase in the coexistence period between weeds and the Convert HD364 grass potentially reduces the pasture support capacity, which will consequently influence animal production and the financial sustainability of the livestock farming in the area. 
A
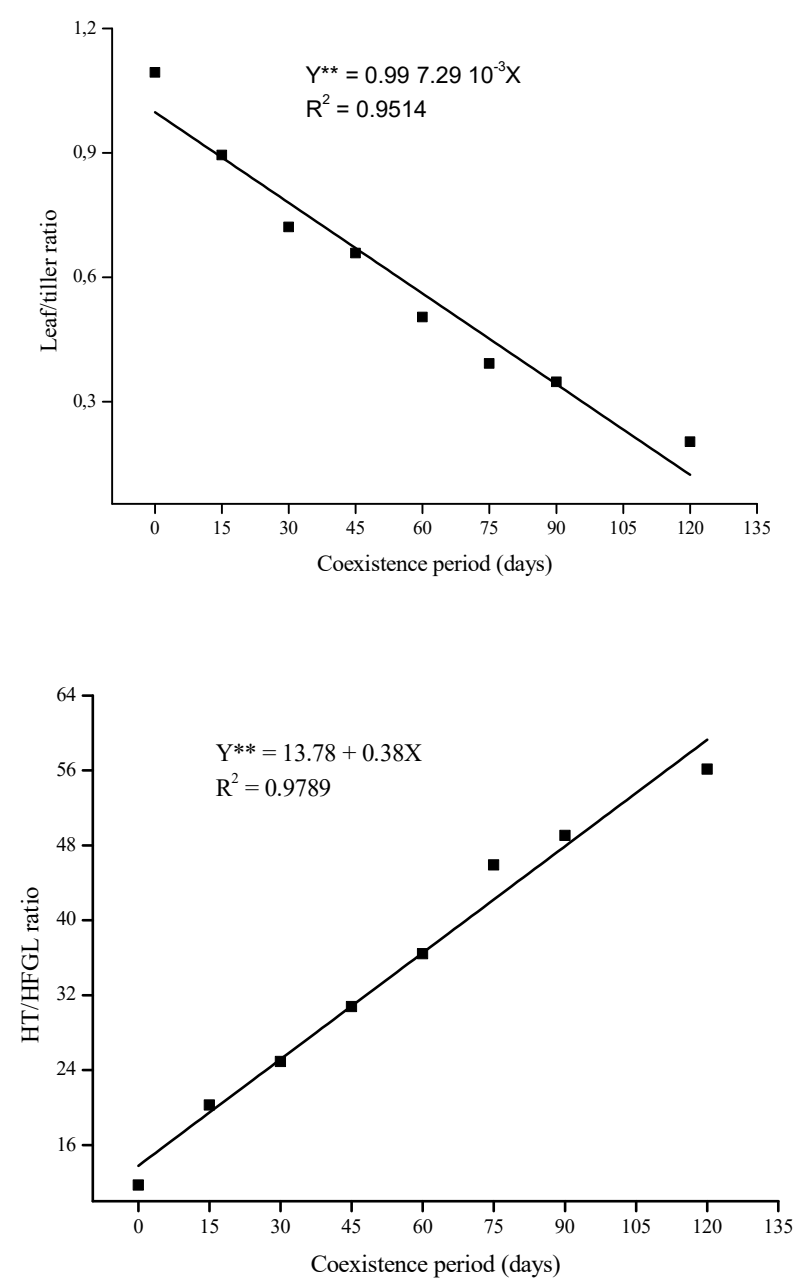

Figure 2. Relationship between leaf/tiller dry matter (A) and proportion between tiller height and first green leaf height (B) obtained in the Convert HD364 grass as a function of weed coexistence periods. ** $\mathrm{P}<0.01$

Table 3. Green leaf (GLDM), green tiller (GTDM), dead material (DMDM), and total dry matter (TDM) obtained as a function of weed coexistence periods

\begin{tabular}{llcccl}
\hline $\begin{array}{l}\text { Coexistence } \\
\left(\mathrm{DAE}^{1}\right)\end{array}$ & GLDM & GTDM & DMDM & TDM & $\begin{array}{l}\text { Reduction } \\
(\%)\end{array}$ \\
\cline { 2 - 6 }$\left(\mathrm{g} \mathrm{m}^{-2}\right)$ & & & & $2915.55 \mathrm{a}$ & --- \\
15 & $1665.51 \mathrm{a}$ & $916.24 \mathrm{a}$ & $333.80 \mathrm{a}$ & $2141.04 \mathrm{~b}$ & 26.56 \\
30 & $1222.81 \mathrm{~b}$ & $708.05 \mathrm{~b}$ & $210.18 \mathrm{~b}$ & $1900.10 \mathrm{c}$ & 34.83 \\
45 & $1127.91 \mathrm{~b}$ & $579.82 \mathrm{c}$ & $192.37 \mathrm{~b}$ & $1712.88 \mathrm{c}$ & 41.25 \\
60 & $986.21 \mathrm{c}$ & $568.46 \mathrm{c}$ & $158.21 \mathrm{c}$ & $1367.17 \mathrm{~d}$ & 53.12 \\
75 & $812.31 \mathrm{c}$ & $502.09 \mathrm{~d}$ & $52.77 \mathrm{~d}$ & $1366.93 \mathrm{~d}$ & 53.11 \\
90 & $847.11 \mathrm{c}$ & $481.43 \mathrm{~d}$ & $38.39 \mathrm{~d}$ & $1209.60 \mathrm{~d}$ & 58.51 \\
120 & $746.41 \mathrm{c}$ & $422.44 \mathrm{e}$ & $40.75 \mathrm{~d}$ & $1108.98 \mathrm{~d}$ & 61.96 \\
\hline F Coexistence & $682.70 \mathrm{c}$ & $372.42 \mathrm{e}$ & $53.85 \mathrm{~d}$ & $30.71^{* *}$ & \\
F Blocks & $11.02^{* *}$ & $55.73^{* *}$ & $119.98^{* *}$ & $0.53^{\mathrm{NS}}$ & \\
CV $(\%)$ & $0.57^{\mathrm{NS}}$ & $0.73^{\mathrm{NS}}$ & $0.50^{\mathrm{NS}}$ & 12.63 & \\
\hline
\end{tabular}

NS - Not significant; ${ }^{* *}$ - Significant at $5 \%$ probability. Means followed by the same letter do not differ statistically from each other by the Scott-Knott test at $5 \%$ probability.

$\backslash 1$ DAE - Days after emergence. 


\section{Nutritional quality of forage}

Neutral detergent fiber (NDF) contents were not influenced by weed coexistence. NDF values did not differ statically from each other $(\mathrm{P}>0.05)$ and were above $60 \%$ (Table 4), which, according to Van Soest (1994), would be the range in which occurs restriction of roughage intake by ruminants.

Table 4. Mean contents of neutral detergent fiber (NDF), acid detergent fiber (ADF), indigestible neutral detergent fiber (iNDF), and total digestible nutrient (TDN) in the dry matter of Convert HD364 grass obtained according to coexistence periods with weeds

\begin{tabular}{llcc}
\hline $\begin{array}{l}\text { Coexistence } \\
\left(\mathrm{DAE}^{\underline{1}}\right)\end{array}$ & NDF & ADF & iNDF \\
\cline { 2 - 4 }$(\% \mathrm{DM})$ & $42.64 \mathrm{~d}$ & $15.92 \mathrm{~d}$ \\
0 & 70.56 & $44.39 \mathrm{~d}$ & $24.81 \mathrm{c}$ \\
30 & 71.49 & $45.45 \mathrm{c}$ & $27.11 \mathrm{~b}$ \\
45 & 72.74 & $53.13 \mathrm{~b}$ & $29.57 \mathrm{~b}$ \\
60 & 72.62 & $54.86 \mathrm{~b}$ & $29.14 \mathrm{~b}$ \\
75 & 68.55 & $56.55 \mathrm{~b}$ & $29.34 \mathrm{~b}$ \\
90 & 67.57 & $57.02 \mathrm{~b}$ & $31.05 \mathrm{~b}$ \\
120 & 69.16 & $61.38 \mathrm{a}$ & $33.58 \mathrm{a}$ \\
\hline F Coexistence & 70.41 & $40.61^{* *}$ & $20.26^{* *}$ \\
F Blocks & $1.99^{\mathrm{NS}}$ & $0.51^{\mathrm{NS}}$ & $0.14^{\mathrm{NS}}$ \\
CV $(\%)$ & $1.36^{\mathrm{NS}}$ & 3.93 & 7.60 \\
\hline
\end{tabular}

NS - Not significant; ${ }^{* *}$ - Significant at $5 \%$ probability. Means followed by the same letter do not differ statistically from each other by the Scott-Knott test at 5\% probability.

$\lfloor$ DAE - Days after emergence.

$\mathrm{ADF}$ and iNDF contents increased as weed coexistence period increased, with values expressively higher $(\mathrm{P}<0.01)$ from 30 and $15 \mathrm{DAE}$, respectively, when compared to the other coexistence periods. Weed coexistence at 120 DAE provided the highest contents of ADF and iNDF $(\mathrm{P}<0.01)$ although the NDF content obtained at 120 DAE was similar $(\mathrm{P}>0.05)$ to those obtained in the other coexistence periods.

$\mathrm{ADF}$ and iNDF values can be used as indicators of diet digestibility and the higher these values are, the worse the food quality and the longer the retention time in the animal rumen, thus affecting the passage rate. High ADF and iNDF contents are related to food quality and also indicate a higher proportion of fibrous constituents more resistant to digestion, such as resistant pentosans, cellulose, lignin, and cutin, which are cell wall components responsible for the low forage digestibility (VAN SOEST, 1994). In addition, NDF together with $\mathrm{ADF}$ and $\mathrm{iNDF}$ are determinants in the repletion process, i.e., the ability of the food to promote a physical filling in the rumen, which directly affects voluntary intake (COSTA et al., 2011, PESQUEIRA-SILVA et al., 2015).

Crude protein $(\mathrm{CP})$ contents were also significantly altered by weeds, with the lowest values $(\mathrm{P}<0.01)$ obtained in coexistence periods equal to or higher than 60 DAE (Table 5).

The coexistence with weeds did not have such a pronounced effect on ADIN contents since only the longest coexistence period (120 DAE) provided the highest content $(\mathrm{P}<0.01)$ when compared to the other studied periods. However, weed interference was notorious on N-ADF contents and followed almost the same pattern obtained for $\mathrm{ADF}$, i.e., the increased coexistence period conditioned higher N-ADF contents and only 15 DAE of coexistence is required to significantly increase the values (Table 5).

ADIN corresponds to the available nitrogen and, when insoluble in acid detergent, consists of protein and nitrogen compounds associated with lignin, tannins, and Maillard products, which are highly resistant to microbial attack and ruminal degradation (NRC, 2001). Nitrogen retained as N$\mathrm{ADF}$ is practically indigestible and is generally associated with lignin and other compounds of difficult degradation (OLIVEIRA et al., 2010). Increases in N-ADF contents may occur when there is an excessive heat production and with the physiological plant age, which may compromise the integrity and availability of nitrogen fraction and, consequently, result in slower degradation rates in the animal's digestive tract (SNIFFEN et al., 1992; POSSENTI et al., 2016). 
Table 5. Percentages of crude protein (CP) in dry matter, acid detergent insoluble nitrogen (ADIN), and nitrogen bound to acid detergent fiber (N-ADF) of Convert HD364 grass obtained as a function of weed coexistence periods.

\begin{tabular}{llll}
\hline $\begin{array}{l}\text { Coexistence } \\
\left(\mathrm{DAE}^{1}\right)\end{array}$ & CP & ADIN & N-ADF \\
\cline { 2 - 4 }$(\% \mathrm{DM})$ & & $0.65 \mathrm{~d}$ \\
15 & $7.38 \mathrm{a}$ & $0.31 \mathrm{~b}$ & $0.96 \mathrm{c}$ \\
30 & $6.57 \mathrm{a}$ & $0.50 \mathrm{~b}$ & $1.19 \mathrm{~b}$ \\
45 & $6.45 \mathrm{a}$ & $0.53 \mathrm{~b}$ & $1.02 \mathrm{c}$ \\
60 & $5.99 \mathrm{a}$ & $0.56 \mathrm{~b}$ & $0.93 \mathrm{c}$ \\
75 & $5.17 \mathrm{~b}$ & $0.58 \mathrm{~b}$ & $0.98 \mathrm{c}$ \\
90 & $5.28 \mathrm{~b}$ & $0.65 \mathrm{~b}$ & $0.99 \mathrm{c}$ \\
120 & $5.01 \mathrm{~b}$ & $0.78 \mathrm{~b}$ & $1.39 \mathrm{a}$ \\
\hline F Coexistence & $4.94 \mathrm{~b}$ & $1.18 \mathrm{a}$ & $10.10^{* *}$ \\
F Blocks & $4.71^{* *}$ & $10.75^{* *}$ & $0.79^{\mathrm{NS}}$ \\
CV $(\%)$ & $1.25^{\mathrm{NS}}$ & $0.64^{\mathrm{NS}}$ & \\
\hline
\end{tabular}

NS - Not significant; ** - Significant at 5\% probability. Means followed by the same letter do not differ statistically from each other by the Scott-Knott test at $5 \%$ probability.

$\lfloor 1$ DAE - Days after emergence.

However, Marchi et al. (2017) stated that the forage canopy structure could also be modified due to the action that weeds exert on the competition for environmental resources, being mineral nutrients one of the factors of a greater dispute between competing individuals. Even though soil fertility has been corrected in the area where the experiment was installed, weeds had the ability to recruit the nutrient. The higher production of fibers as stem in relation to the production of green leaf (Figure 2A) associated with the competition for available nitrogen in the soil is the reason why there was a low conversion of nitrogen absorbed by the Convert HD364 grass into nitrogen compounds of easy degradation and concomitantly with a higher conversion into nitrogen compounds of difficult degradation (Table 5).

In vitro digestibility of organic matter (IVDOM) and total digestible nutrient (TDN) decreased in linear proportions $(\mathrm{P}<0.01)$ as the weed coexistence period increased (Figures $3 \mathrm{~A}$ and $3 \mathrm{~B}$ ). The same negative influence of weeds is also observed on the digestible (DE) and metabolizable energies (ME) of the Convert HD364 grass, with linear reductions $(\mathrm{P}<0.01)$ with the progression of common coexistence (Figure 3C and 3D). In fact, the influence of weeds on IVDOM and TDN is justified since there were negative interferences on the different fractions of fiber and crude protein of the Convert HD364 grass. The reduction in the DE and $\mathrm{ME}$ values is also logical considering that a great part of the energy assessment of foods is estimated from TDN.

The increase of fibrous fractions (Table 4) and changes that occurred in the chemical composition, especially the reduction in CP contents (Table 5), had a direct impact on IVDOM contents of the Convert HD364 grass. In turn, digestibility represents how much of the forage consumed will be effectively digested in the animal gastrointestinal tract for further absorption and use of compounds in metabolic pathways (NRC, 2001). In addition, digestibility also influences the feed passage rate in the gastrointestinal tract and may compromise the productive performance of the animal by 10 to $40 \%$. As a rule, low-digestion plant tissues correlate negatively with $\mathrm{CP}$, positively with fiber and lignin contents and require a longer rumen retention time for the fibrolytic processes to occur (OLIVEIRA et al., 2016).

The concentration of potentially digestible components, comprising soluble carbohydrates, protein, minerals, and other cellular contents tend to decrease as the plants mature. At the same time, the proportion of lignin, cellulose, hemicellulose, and other indigestible fractions, such as cuticle and silica, increase and hence decreases in digestibility are expected (NRC, 2001).

In this study, it is evident that the presence of weeds conditioned the alteration of structural and non-structural carbohydrate portions and probably increased the proportion of lignin, cellulose, hemicellulose, and other indigestible fractions (Table 4).

The total digestible nutrient (TDN) contents represent better the nutritional food quality, in which the higher the TDN values are, more nutrients will be available and, consequently, higher the digestible energy (DE) availability for animal yield (MORAIS; NEPOMUCENO; ALMEIDA, 2016). 
Tropical forage grasses can be considered of low nutritional quality when they have TDN lower than $60 \%$ (VALADARES FILHO et al., 2016), values obtained when the coexistence period with weeds was equal to or higher than 90 DAE (Figure 3B).
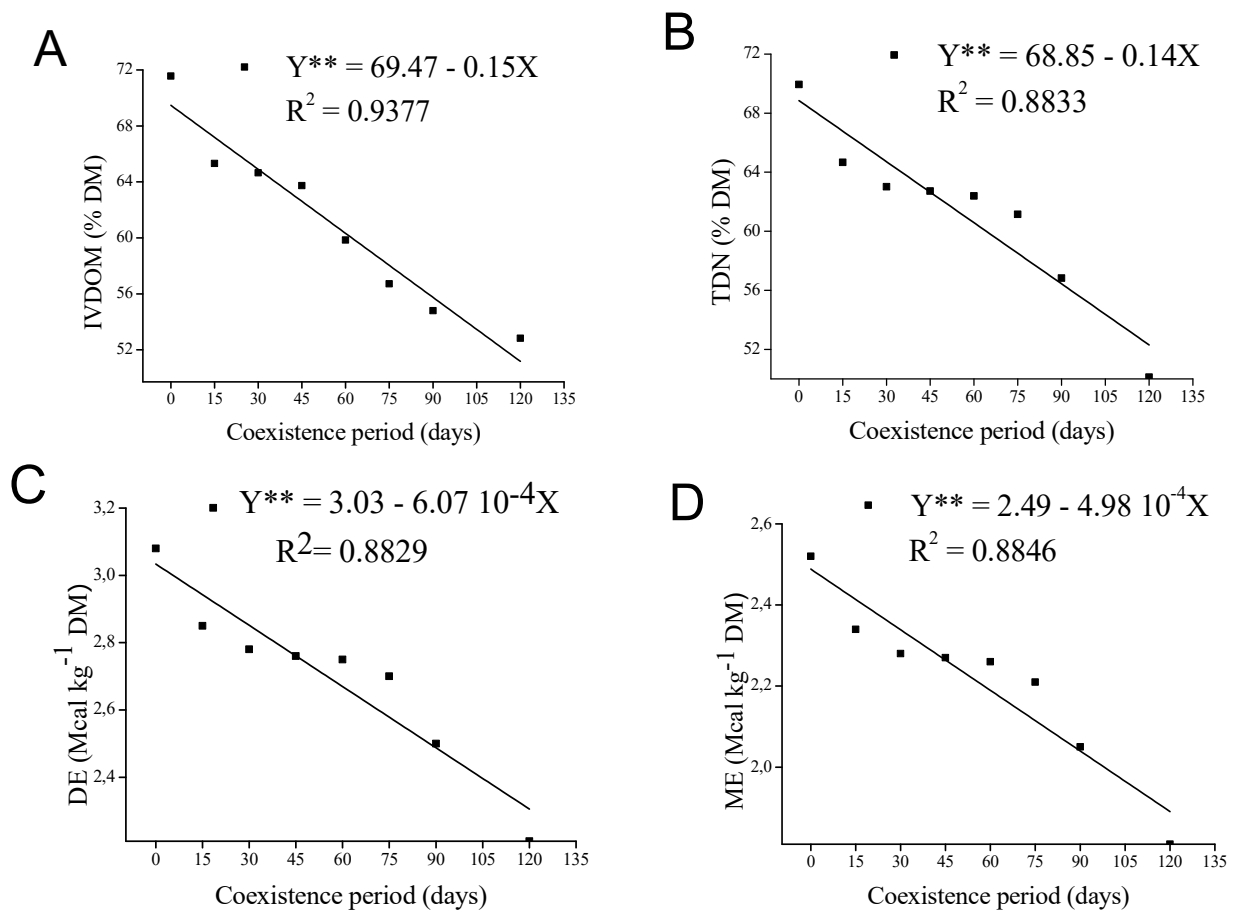

Figure 3. Contents of in vitro digestibility of organic matter - IVDOM (A), total digestible nutrient - TDN (B), digestible energy - DE (C), and metabolizable energy - ME (D) obtained in the Convert HD364 grass as a function of weed coexistence periods. ** $\mathrm{P}<0.01$

\section{Potential gas production}

Assessments regarding the potential gas production performed in the Convert HD364 grass showed that the coexistence with weeds contributes to an increase in GHG emission. The total gas production was higher when the coexistence period was 120 DAE $(\mathrm{P}<0.01)$. However, the total gas emission decreased by $4.3 \%$ when the period was 90 DAE and between 14.8 and $17.0 \%$ in the periods of 45,60 , and 75 DAE. The lowest $(\mathrm{P}<0.01)$ total gas emission was $63.82 \mathrm{~mL} \mathrm{~g}^{-1} \mathrm{DM}$ and was obtained under the condition where there was no coexistence (0 DAE) with the weed community (Table 6).

Table 6. Total gas volume, methane $\left(\mathrm{CH}_{4}\right)$ volume, and carbon dioxide $\left(\mathrm{CO}_{2}\right)$ volume produced by the dry matter of the Convert HD364 grass as a function of the coexistence periods with weeds

\begin{tabular}{llcl}
\hline $\begin{array}{l}\text { Coexistence } \\
\left(\mathrm{DAE}^{\underline{1}}\right)\end{array}$ & \multicolumn{2}{l}{$\mathrm{CH}_{4}$} & $\mathrm{CO}_{2}$ \\
\cline { 2 - 4 }$\left(\mathrm{mL} \mathrm{g}{ }^{-1} \mathrm{DM}\right)$ & $8.19 \mathrm{f}$ & $52.25 \mathrm{~g}$ \\
15 & $63.82 \mathrm{e}$ & $9.16 \mathrm{e}$ & $51.42 \mathrm{f}$ \\
30 & $75.42 \mathrm{~d}$ & $9.54 \mathrm{e}$ & $62.20 \mathrm{f}$ \\
45 & $77.30 \mathrm{~d}$ & $10.27 \mathrm{~d}$ & $69.21 \mathrm{e}$ \\
60 & $83.14 \mathrm{c}$ & $10.67 \mathrm{c}$ & $77.02 \mathrm{c}$ \\
75 & $85.34 \mathrm{c}$ & $11.63 \mathrm{~b}$ & $73.92 \mathrm{~d}$ \\
90 & $83.30 \mathrm{c}$ & $12.36 \mathrm{a}$ & $81.28 \mathrm{~b}$ \\
120 & $95.87 \mathrm{~b}$ & $12.12 \mathrm{a}$ & $87.98 \mathrm{a}$ \\
\hline F Coexistence & $100.14 \mathrm{a}$ & $127.68^{* *}$ & $141.02^{* *}$ \\
F Blocks & $100.96^{* *}$ & $0.18^{\mathrm{NS}}$ & $0.13^{\mathrm{NS}}$ \\
CV $(\%)$ & $0.21^{\mathrm{NS}}$ & 2.51 & 2.79 \\
\hline
\end{tabular}

NS - Not significant; ** - Significant at 5\% probability. Means followed by the same letter do not differ statistically from each other by the Scott-Knott test at $5 \%$ probability. $\backslash \underline{1} \mathrm{DAE}$ - Days after emergence. 
The potential of $\mathrm{NH}_{4}$ emission by the Convert HD364 grass followed practically the same pattern regarding the effect of coexistence with weeds, with emissions above $12.10 \mathrm{~mL} \mathrm{~g}^{-1} \mathrm{DM}$ obtained in periods of 90 and $120 \mathrm{DAE}$ and 9.16 and $9.54 \mathrm{~mL} \mathrm{~g}^{-1} \mathrm{DM}(\mathrm{P}<0.01)$ in the periods of 15 and 30 DAE, respectively. The coexistence for periods from 45 to 75 DAE provided intermediate values of the potential of $\mathrm{NH}_{4}$ emission, but the absence of coexistence (0 DAE) provided the lowest $(\mathrm{P}<0.001) \mathrm{NH}_{4}$ emission of only $8.19 \mathrm{~mL} \mathrm{~g}^{-1} \mathrm{DM}$ (Table 6).

The coexistence period of 120 DAE was also responsible by the highest value of $\mathrm{CO}_{2}$ emission for the Convert HD364 grass $(\mathrm{P}<0.01)$, with a production of $87.98 \mathrm{~mL} \mathrm{~g}^{-1} \mathrm{DM}$. The coexistence for periods of 45 to 90 DAE provided intermediate levels, while values of 51.42 and 62.20 $\mathrm{mL} \mathrm{g}^{-1} \mathrm{DM}$ and similar to each other $(\mathrm{P}>0.05)$ were obtained in the periods of 15 and 30 DAE, respectively. Again, the absence of coexistence $(0$ DAE) with weeds conditioned the lowest value $(\mathrm{P}<0.01)$ when compared to $\mathrm{CO}_{2}$ emission levels obtained in the other studied coexistence periods (Table 6).

In the feeding of animals with high-energy requirements, productivity indices alone lose focus and the nutritive value of forage plants becomes more prominent since this qualitative aspect interferes directly with the digestion process, affecting animal performance (PEREIRA, 2013). Most of the food nutrients, mainly energy and protein sources, are transformed into short-chain fatty acids (SCFA), microbial mass, and gases such as $\mathrm{CH}_{4}, \mathrm{CO}_{2}$, nitrous oxide $\left(\mathrm{N}_{2} \mathrm{O}\right)$, and hydrogen $\left(\mathrm{H}_{2}\right)$ (BAKER, 1999; CHAVES et al., 2006).

In general, gas production tends to increase the lower the nutritional quality and the digestibility of the food ingested are, being great the contribution of the fibrous fraction of the food for the production of total gases (MORGADO et al., 2012). This is because more fibrous foods remain in the rumen longer and stimulate the development of microbial biomass with cellulolytic and methanogenic activity, in which the longer the residence time of particles inside the rumen is, the higher the amount of $\mathrm{NH}_{4}$ produced per unit of digested forage (ARCHIMEDDE et al., 2011). In addition, $\mathrm{CO}_{2}$ and $\mathrm{NH}_{4}$ production represent losses of 2 to $12 \%$ of the energy consumed in the food, besides contributing to global warming (ALUWONG; WUYEP; ALLAM, 2011).

This fact was verified in the present study since the values of total gas volume, $\mathrm{NH}_{4}$ volume, and $\mathrm{CO}_{2}$ volume (Table 6 ) increased relatively as the nutritional quality of the Convert HD364 grass decreased, causing considerable losses in the energy values of the food (Figures $3 \mathrm{C}$ and 3D).

RESUMO: O aumento da população mundial tem elevado a demanda por proteínas de origem animal, obrigando a pecuária a tornar-se produtiva, eficaz e ao mesmo tempo sustentável. O objetivo deste estudo foi avaliar o efeito da convivência de plantas daninhas sobre a produtividade, qualidade nutricional e potencial de produção de gases de efeito estufa (GEE) pelo capim Convert HD364 (Urochloa hibrida cv. Mulato II) em condição de renovação de pastagem. O experimento foi instalado no delineamento experimental em blocos casualizados, com quatro repetições e os tratamentos constituídos por oito períodos de convivência: 0 , 15 , 30 , 45, 60, 75, 90 e 120 dias após a emergência das plântulas. Avaliações fitossociológicas foram realizadas na comunidade infestante ao final de cada período de convivência. O capim Convert HD364 foi avaliado quanto aos parâmetros morfológicos, químico-bromatológicos e quanto ao potencial de emissão de GEE. Verificou-se que a produtividade, a qualidade nutricional e o valor energético do capim Convert HD364 diminui proporcionalmente ao aumento do período de convivência com as plantas daninhas. A não convivência com plantas daninhas condiciona melhor digestibilidade in vitro da matéria orgânica e, consequentemente, diminui o potencial de emissão de GEE pela matéria seca do capim Convert HD364.

PALAVRAS-CHAVE: Urochloa hibrida $c v$. Mulato II. Morfometria. Produtividade. Valor nutricional. Digestibilidade. Valor energético.

\section{REFERENCES}

ALUWONG, T; WUYEP, P. A.; ALLAM, L. Livestock-environment interactions: Methane emissions from ruminants. African Journal of Biotechnology, Nairobi, v. 10, n. 8, p. 1265-1269, 2011. https://doi.org/10.5897/AJB10.1117 
ALVARES, C. A.; STAPE, J. L.; SENTELHAS, P. C.; GONÇALVES, J. L. M; GERD SPAROVEK, G. Köppen's climate classification map for Brazil. Meteorologische Zeitschrift, Stuttgart, v. 22, n. 6, p.711-728, 2014. https://dx.doi.org/10.1127/0941-2948/2013/0507

ARCHIMÈDE, H.; EUGÈNE, M.; MARIE MAGDELEINE, C.; BOVAL, M.; MARTIN, C.; MORGAVI, D.P.; LECOMTE, P.; DOREAU, M. Comparison of methane production between $\mathrm{C} 3$ and $\mathrm{C} 4$ grasses and legumes. Animal Feed Science and Technology, v. 166-167, n. 11, p. 59-64, 2011. Doi: https://doi.org/10.1016/j.anifeedsci.2011.04.003

ARGEL, P. J.; MILES, J. W.; GUIOT, J. D.; CUADRADO, H.; LASCANO, C. E. Cultivar Mulato II (Brachiaria hibrida CIAT 36087): Gramínea de alta qualidade e produção forrageira, resistente às cigarrinhas e adaptada a solos tropicais ácidos. Boletim. Cali: CIAT, 2007. Disponível em: http://ciatlibrary.ciat.cgiar.org/Articulos_Ciat/mulato_ii_portugues.pdf. Acesso em: 28 jan. 2019.

BAKER, S. K. Rumen methanogens, and inhibition of methanogenesis. Australian Journal of Agricultural Research, v. 50, n. 8, p. 1293-1298, 1999. https://doi.org/10.1071/AR99005

BARBOSA, J. C.; MALDONADO JÚNIOR, W. Experimentação agronômica \& AgroEstat: Sistemas para análises estatísticas e ensaios agronômicos, Gráfica Multipress Ltda, Jaboticabal, 2015. 396 p.

BELLÉ, J. R.; MARCHI, S. R.; MARTINS, D.; SOUSA. A. C.; PINHEIRO, G. H. R. Nutritional value of marandú palisade grass according to increasing coexistence periods with weeds. Planta Daninha, Viçosa, v. 36, p. 1-11, 2018. http://dx.doi.org/10.1590/s0100-83582018360100070

BERCHIELLI, T. T.; MESSANA, J. D.; CANESIN, R. C. Produção de metano entérico em pastagens tropicais. Revista Brasileira de Saúde e Produção Animal, Salvador, v.13, n. 4, p.954-968, 2012. http://dx.doi.org/10.1590/S1519-99402012000400010

BITENCOURT JUNIOR, D; SIEWERDT, L.; FERREIRA, O. G. L. Potencial produtivo do capim-mulato e características morfológicas em crescimento diferido de verão. Revista Brasileira de Agrociência, Pelotas, v. 14, n.3-4, p.147-154, 2008. DOI: HTTP://DX.DOI.ORG/10.18539/CAST.V14I3.1944

BLAXTER, K. L. The nutritive value of feeds as sources of energy: a review. Journal of Dairy Science, v. 39, n. 10, p. 1396-1424, 1956. https://doi.org/10.3168/jds.S0022-0302(56)94865-2

CARVALHO, R. M.; PIMENTEL, R. M.; FONSECA, D. M.; SANTOS, M. E. R. Effects of weed plants on tiller characteristics in Brachiaria pasture. Boletim da Indústria Animal, Nova Odessa, v. 73, n. 2, p.103-110, 2016. DOI: http://dx.doi.org/10.17523/bia.v73n2p103

CASAGRANDE, D. R.; RUGGIERI, A. C.; JANUSCKIEWICZ, E. R.; GOMIDE, J. A.; REIS, R. A.; VALENTE, A. L. S. Morphogenetic and structural traits of Marandugrass pasture under continuous grazing with different forage supply. Revista Brasileira de Zootecnia, Viçosa, v. 39, n. p. 2108-2115, 2010. http://dx.doi.org/10.1590/S1516-35982010001000002

CHAVES, A. V.; THOMPSON, L. C.; IWAASA, A. D.; SCOTT, S. L.; OLSON, M. E.; BENCHAAR, C.; VEIRA, D. M.; MCALLISTER, T. A. Effect of pasture type (alfafa vs. grass) on methane and carbon dioxide production by yearling beef heifers. Canadian Journal of Animal Science, v. 86, n. 3, p. 409-418, 2006. Doi: https://doi.org/10.4141/A05-081

COSTA, V. A. C.; DETMANN, E.; VALADARES FILHO, S. C.; PAULINO, M. F.; CARVALHO, I. P. C.; MONTEIRO, L. P. Intake and digestibility in cattle under grazing during rainy season and supplemented with different sources of nitrogenous compounds and carbohydrates. Revista Brasileira de Zootecnia, Viçosa, v. 40, n. 8, p. 1788-1798, 2011. http://dx.doi.org/10.1590/S1516-35982011000800024 
FLEITAS, A. C.; PAIVA, L. M.; FERNANDES, H. J.; DUARTE, C. F. D.; FALCÃO, K. R. S.; BISERRA, T. T. Morphogenic characteristics of convert HD364® grass fertilized with different phosphorus sources. Revista Agrarian, Dourados, v. 11, n. 3, p. 59-67, 2018. DOI: https://doi.org/10.30612/agrarian.v11i39.5362

GLÉRIA, A. A.; SILVA, R. M.; SANTOS, A. P. P.; SANTOS, K. J. G.; PAIM, T. G. Beef cattle production in crop-livestock systems. Archivos de Zootecnia, Córdoba, v. 66, n. 253, p.141-150, 2017.

DOI. 10.21071/az.v66i253.2138

LEAL, D. M.; FRANÇA, A. F. S.; OLIVEIRA, L. G.; CORREA, D. S.; ARNHOLD, E.; FERREIRA, R. N.; BASTOS, D. C.; BRUNES, L. C. Fracionamento de carboidratos e proteínas da Brachiaria híbrida 'Mulato II' sob adubação nitrogenada e regime de cortes. Archivos de Zootecnia, Córdoba, v. 66, n 254, p. 181-188, 2017.

LEMAIRE, G.; HODGSON, J.; CHABBI, A. Grassland productivity and ecosystem services. Cab International, Wallingford, 2011, 287p. https://doi.org/10.1079/9781845938093.0000

LICITRA, G.; HERNANDEZ, T. M.; VAN SOEST, P. J. Standardization of procedures for nitrogen fractionation of ruminants feeds. Animal Feed Science and Technology, v. 57, n. 4, p. 347-358, 1996. https://doi.org/10.1016/0377-8401(95)00837-3

LOURENÇO, A. A.; MOTA, R. V.; SANCHES, J. L.; MARQUES, R. F.; MARCHI, S. R. WEED Interference in the establishment of Urochloa ruziziensis. PInata Daninha, v. 37, Epub Sep 09, 2019.

http://dx.doi.org/10.1590/s0100-83582019370100077

MACEDO, M. C. M. Crop and livestock integration: the state of the art and the near future. Revista Brasileira de Zootecnia, Viçosa, v. 38, Edição Especial, p. 133-146, 2009. http://dx.doi.org/10.1590/S151635982009001300015

MARCHI, S. R.; BELLÉ, J. R.; FOZ, C. H.; FERRI, J.; MARTINS, D. Weeds alter the establishment of Brachiaria brizantha cv. Marandu. Tropical Grasslands, Cali, v. 5, n. 2, p.85-93, 2017. DOI:

https://doi.org/10.17138/tgft(5)85-93

MARCHI, S. R.; SILVA, H. M.; FERREIRA, C. F.; MARQUES, R. F; MORAES, J. B. Interference of noxious shrubs on grazing behavior by bovines. Planta Daninha, Viçosa, v. 37, n. 1, p. 1-10, 2019. DOI: http://dx.doi.org/10.1590/s0100-83582019370100009

MEZZALIRA, J. C.; CARVALHO, P. C. F.; FONSECA, L.; BREMM, C.; CANGIANO, C.; GONDA, H. L.; LACA, E. A. Behavioural mechanisms of intake rate by heifers grazing swards of contrasting structures. Applied Animal Behaviour Science, v. 153, p. 1-9, 2014. https://doi.org/10.1016/j.applanim.2013.12.014

MONQUERO, P. A.; HIRATA, A. C.; PITELLI, R. A. Métodos de levantamento da colonização de plantas daninhas. In: MONQUERO PA (Org.) Aspectos da biologia e manejo das plantas daninhas, Editora RiMa, São Carlos, 2014. p. 103-127.

MORAIS, L. F; NEPOMUCENO, D. D.; ALMEIDA, J. C. C. Low nutritive value forage treatments for ruminants - a review. Acta Tecnológica, São Luís, v. 11, n. 1, p. 67-81, 2016. Disponível em:

http://portaldeperiodicos.ifma.edu.br/index.php/actatecnologica/article/view/443. Acesso em: 13 Jan. 2018.

MORGADO, E. S.; EZEQUIEL, J. M. B.; GALZERANO, L.; HOMEM JÚNIOR, A. C. In vitro production of $\mathrm{CH}_{4}$ and $\mathrm{CO}_{2}$ in ruminal fluid of sheep fed diets containing high starch or neutral detergent fiber soluble associated or not with sunflower oil. Revista Científica de Produção Animal, Paraíba, v. 14, n. 1, p. 81-84, 2012. DOI: http://dx.doi.org/10.15528/2176-4158/rcpa.v14n1p81-84

NRC - Nutrient requirements of dairy cattle. 7th rev. edn. (National Academy of Sciences: Washington, DC), 2001, 381p. Disponível em: https://profsite.um.ac.ir/ kalidari/software/NRC/HELP/NRC\%202001.pdf. Acesso em: 09 Jul. 2018 
OLIVEIRA, L. B.; PIRES, A. J. V.; CARVALHO, G. G. P.; RIBEIRO, L. S. O.; ALMEIDA, V. V.; PEIXOTO, C. A. M. Losses and nutritional value of corn, Sudan sorghum, forage sorghum and sunflower silages. Revista Brasileira de Zootecnia, Viçosa, v. 39, n. 1, p. 61-67, 2010. http://dx.doi.org/10.1590/S151635982010000100008

OLIVEIRA, A. P.; CASAGRANDE, D. R.; BERTIPAGLIA, L. M. A.; BARBERO, R. P.; BERCHIELLI, T. T.; RUGIERI, C. C.; REIS, R. A. Supplementation for beef cattle on Marandu grass pastures with different herbage allowances. Animal Production Science, v. 56, n. 1, p. 123-129, 2016. https://doi.org/10.1071/AN14636

PASCHOALOTO, J. R.; EZEQUIEL, J. M. B.; ALMEIDA, M. T. C.; FÁVARO, M. R.; HOMEM JÚNIOR, A. C.; CARVALHO, V. B.; PEREZ, H. L. Inclusion of crude glycerin with different roughages changes ruminal parameters and in vitro gas production from beef cattle. Ciência Rural, Santa Maria, v. 46, n. 5, p.889-894, 2016. http://dx.doi.org/10.1590/0103-8478cr20151088

PEDREIRA, M. S.; OLIVEIRA, S. G.; BERCHIELLI, T. T.; PRIMAVESI, O. Aspectos relacionados com a emissão de metano de origem ruminal em sistemas de produção de bovinos. Archives of Veterinary Science, Curitiba, v. 10, n. 3, p. 24-32, 2005. DOI: http://dx.doi.org/10.5380/avs.v10i3.5122

PEREIRA, L. G. R. Evaluation methods and enteric methane mitigation strategies in ruminants. Revista Colombiana de Ciencias Pecuarias, v. 26, Suplemento, p. 264-277, 2013. Disponível em: https://aprendeenlinea.udea.edu.co/revistas/index.php/rccp/article/view/324839/20782326. Acesso em: 18 Jan. 2019.

PESQUEIRA-SILVA, L. C. R.; ZERVOUDAKIS, J. T.; ARAÚJO, C. V.; CABRAL, L. S.; HATAMOTOZERVOUDAKIS, L. K.; OLIVEIRA, A. A.; SILVA-MARQUES, R. P. Nutritional parameters of Nellore heifers grazing in grass marandu receiving energy, protein and multiple supplement the dry-rainy transition period. Semina: Ciências Agrárias, Londrina, v. 36, n. 5, p. 3293-3302, 2015. DOI: http://dx.doi.org/10.5433/1679-0359.2015v36n5p3293

POSSENTI, R. A.; ARANTES, A. M.; BRÁS, P.; ANDRADE, J. B.; FERRARI JÚNIOR, E. Nutritional evaluation of safflower silage and biomass, seed and oil production. Boletim da Indústria Animal, Nova Odessa, v. 73, n. 3, p. 2326-243, 2016. Doi: http://dx.doi.org/10.17523/bia.v73n3p236

PRIMAVESI, O.; FRIGHETTO, R. T. S.; PEDREIRA, M. S.; LIMA, A. L.; BERCHIELLI, T. T.; BARBOSA, P. F. Metano entérico de bovinos leiteiros em condições tropicais brasileiras. 2004. Pesquisa Agropecuária Brasileira, Brasília, v. 39, n. 3, p. 277-283, 2004. http://dx.doi.org/10.1590/S0100-204X2004000300011

SANCHES, S. S. C.; GALVÃO, C. M. L.; RODRIGUES, R. C.; SIQUEIRA, J. C.; JESUS, A. N. R.; ARAÚJO, J. S.; SOUSA, T. V. R.; SILVA JUNIOR, A. L. Produção de forragem e características morfofisiológicas do capim-mulato cultivado em latossolo do cerrado em função de doses de nitrogênio e potássio. Revista Brasileira de Agropecuária Sustentável, Viçosa, v.3, n.1, p.81-89, 2013.

SANTOS, L. M.; SIQUEIRA, F. L. T.; SIQUEIRA, G. B; CALÇADO, G. P. A. Potencial de estabelecimento da Brachiaria hibrida cultivar Mulato II (Convert HD364) no estado do Tocantins. Nativa, Sinop, v. 3, n. 4, p. 224-232, 2015. DOI: 10.14583/2318-7670.v03n04a01

SANTOS, M. E. R.; FONSECA, D. M.; GOMES, V. M.; PIMENTEL, R. M.; SILVA, G. P.; ALBINO, R. L. Structure of signalgrass in relation to weeds. Acta Scientiarum - Animal Sciences, Maringá, v. 33, n. 3, p. 233-239, 2011. DOI: 10.4025/actascianimsci.v33i3.10439

SEKER, E. The determination of the energy values of some ruminant feeds by using digestibility trial and gas test. Revue de Médicine Véterinaire, Toulouse, v. 153, n. 5, p.323-330, 2002. Disponível em: https://www.revmedvet.com/2002/RMV153_323_330.pdf. Acesso em: 06 Jan. 2019 
SILVA, D. J.; QUEIROZ, A. C. Análise de alimentos (métodos químicos e biológicos). 3.ed. Viçosa, MG: Universidade Federal de Viçosa, 2002. 235p.

SNIFFEN, C. J; O’CONNOR, J. D.; VAN SOEST, P. J.; FOX, D. G.; RUSSELL, J. B. A net carbohydrate and protein system for evaluating cattle diets: II. Carbohydrate and protein availability. Journal of Animal Science, v. 70, n. 11, p. 3562-3577, 1992. Doi: https://doi.org/10.2527/1992.70113562x

VALADARES FILHO, S. C.; SILVA, L. F. C.; GIONBELLI, M. P.; ROTTA, P. P.; MARCONDES, M. I.; CHIZZOTTI, M. L.; PRADOS, L. F. Exigências nutricionais de zebuínos puros e cruzados. BR-Corte 3st ed. Viçosa (MG): UFV, DZO, 2016. 327 p. DOI: http://dx.doi.org/10.5935/978-85-8179-111-1.2016B001

VAN SOEST, P. J. Nutritional ecology of the ruminant. 2nd ed. Ithaca, NY: Cornell University Press, 1994. 476p.

VENDRAMINI, J. M. B.; SOLLEMBERGER, L. E.; LAMB, G. C.; FOSTER, J. L.; LUI, K.; MADDOX, M. K. Forage accumulation, nutritive value, and persistence of 'Mulato II' Brachiaria grass in Northern Florida. Crop Science, Madison, v. 52, n. 2, p. 914-922, 2012. DOI: 10.2135/cropsci2011.06.0338

VILELA, L., SOARES, W. V; SOUSA, D. M. G.; MACEDO, M. C. M. Calagem e adubação para pastagens. In: SOUSA, D.M.G.; LOBATO E. (Eds.) Cerrado: Correção do solo e adubação. Planaltina, DF: Embrapa Informação Tecnológica, 2004. p. 367-384. 